\title{
An overview of anthropogenic electromagnetic radiations as risk to pollinators and pollination
}

\author{
Sanjay Kumar* \\ Department of Zoology, Kamla Nehru Institute of Physical and Social Sciences, Sultanpur \\ (U.P.), India \\ Vinay Kumar Singh \\ Zoological Survey of India, Kolkata (West Bengal), India \\ Pashupati Nath \\ Department of Civil Engineering, Roorkee College of Engineering, Roorkee, Haridwar \\ (Uttarakhand), India

\section{PC Joshi} \\ Department of Zoology and Environment Science, Gurukula Kangri Vishwavidyalaya, Haridwar \\ (Uttarakhand), India \\ *Corresponding author. Email: kumarsanjaynitin2011@gmail.com
}

\section{How to Cite}

Kumar S. et al. (2020). An overview of anthropogenic electromagnetic radiations as risk to pollinators and pollination. Journal of Applied and Natural Science, 12(4):675 - 681. https://doi.org/10.31018/jans.v12i4.2420

\begin{abstract}
Pollinators play a key functional role in most terrestrial ecosystems and provide important ecosystem service to maintain wild plant communities and agricultural productivity. The decline in pollinators has been related to anthropogenic disturbances such as habitat loss, alterations in land use, and climate change. The surge in mobile telephony has led to a marked increase in electromagnetic fields in the atmosphere, which may affect pollinator and pollination. Several laboratory studies have reported negative effects of electromagnetic radiation on reproduction, development, and navigation in insects. The abundance of insects such as the beetle, wasp, and hoverfly, decreased with electromagnetic radiation(EMR), whereas the abundance of underground-nesting wild bees and bee fly unexpectedly increased with EMR. Potential risks for pollinators and biodiversity are anthropogenic radiofrequency electromagnetic radiation (AREMR) (light, radiofrequency). Artificial light at night (ALAN) can alter the function and abundance of pollinator. Evidence of impacts of AREMR is not adequate due to a lack of high quality, fieldrealistic studies. Whether pollinators experiencing a threat of ALAN or AREMR, while major knowledge gap exists. In this review, the effects of EMR on wild pollinator groups such as wild bees, hoverflies, bee flies, beetles, butterflies, and wasps etc. have been highlighted. Researchers are also recommended for further study on the effects of EMR on insects. This study will be significant to conserve pollinators and other important insects.
\end{abstract}

Keywords: Anthropogenic, Electromagnetic, Pollinator, Radiations, Risk

\section{INTRODUCTION}

Insects are a major group of animals on the earth and occur everywhere. They were the first organisms to successfully colonize land and were most beneficiaries to humankind in many ways from ancient time. The insects play an important role in maintaining the cycle of nutrients, protection, soil regeneration and pollination of phanerogamic plants (Singh, 1988; Bhatia, et al., 1995; Singh, 1997; Dag and Gazit, 2000, Larson, et al., 2001, Evenhuis et al., 2008; Halder, et al., 2019; Hunicken, et al., 2020; Sawe, et al.,2020). About 85\% of the flowering plant species depend upon animals, mostly insects for pollination and worldwide total annual economic value of crop pollination is estimated about \$153 billion (Gallai, et al., 2009). Pollinators play a key functional role in most terrestrial ecosystems and provide important ecosystem service to maintain wild plant communities and agricultural productivity (Klein et al. 2007; Kremen et al. 2007; Potts et al. 2010).

Pollinators have many benefits in nature and for humankind, but they are facing multiple anthropogenic threats. Over the past time, many studies have cautioned about the decline of pollinators (Ashman, et al., 2004; Biesmeijer, et al., 2006; Pauw, 2007; Goulson, et al., 2008; Burkle, et al., 2013; Godfray, et al., 2015; Aguero, et al., 2020, De Santis and Chacoff, 2020; Marques, et al., 2020). The urbanization and use of wireless technologies, including mobile (5G, internet 
of things) are responsible for the proliferation of anthropogenic electromagnetic radiations (EMR). Anthropogenic radiofrequency electromagnetic radiation, artificial light at night emitted from power lines and used in wireless technologies were reported as an additional growing threat to pollinators (Adam, et al., 2019). Lack of high quality scientific studies led to unavailability of information on the anthropogenic EMR as a risk to pollinators. Only a few studies provided evidence on the effect of artificial light at night and anthropogenic radiofrequency electromagnetic radiation on alteration in pollinator communities, pollination and fruit set. Some researchers provided some evidence on the honey bee Apis mellifera and other invertebrates, which can detect EMR and use it for orientation or navigation. Studies also revealed that AREMR influences abundance or diversity of pollinators and reported positive and negative effects depending on the pollinator group and geographical locations. Therefore, anthropogenic EMR (ALAN or AREMR) is a significant threat to insect pollinators, ecosystems and humanity (Adam, et al., 2019). The anthropogenic disturbances such as alterations in land use, loss of habitat and climate change are liable for pollinators to decline (Kearns, et al., 1998; Aguilar, et al., 2006; Hegland, et al., 2009; Potts, et al., 2006; Potts et al., 2010; Chiawo et al., 2017; Dimobe et al., 2017; Stein et al., 2018; Tangtorwongsakul, et al., 2018). Due to exponential use of mobile telephony during recent years, pronounced increase of electromagnetic fields has been reported in the environment (Lazaro, et al., 2016). Studies reported the harmful effects of electromagnetic exposure for different living organisms, from invertebrates to vertebrates, plants and bacteria (Cucurachi, et al. 2013; Balmori, 2015, Malkemper, et al., 2018, Driessen, et al., 2020).

The effects of electromagnetic radiation have been reported by a majority of studies on model species such as fruit fly (Drosophila melanogaster) and the honeybee (Apis mellifera). The electromagnetic radiation delays the development of fruit fly (Atli and U" nlu" 2006) and affect negatively on reproductive success (Panagopoulos, et al. 2004; Atli and U" nlu" 2006, 2007; Panagopoulos and Margaritis, 2010; Panagopoulos, et al. 2010; Chavdoula, et al. 2010), positive effect (Weisbrot, et al., 2003) and no effects (Vijver, et al. 2013) due to DNA fragmentation and reproductive cell death (Chavdoula, et al. 2010; Panagopoulos, et al. 2007, 2010). Studies reported the effect of radiation on honey bee in decreasing colony strength and oviposition rate (Sharma and Kumar, 2010; Sahib, 2011), and induces swarming behaviour (Favre, 2011). Electromagnetic radiation also interferes with honeybee navigation in honey bee (Kirschvink et al. 2001; Wajnberg, et al. 2010; Valkova and Vacha 2012; Balmori 2015). Studies reported that exposure to electromagnetic smog, honeybees are often unable to return to their hives, which lead to colony collapse (Harst, et al.
2006; Warnke 2009; Favre, 2011; Sharma and Kumar, 2010; Sahib, 2011). The effects of radiofrequency magnetic fields has been reported on the interruption of magnetoreception in the American cockroach (Vacha, et al. 2009). In another study, the influence of electromagnetic radiation reported on olfactory memory, visual and ability to locate food (Cammaerts, et al., 2012), orientation, locomotion in ants (Cammaerts, et al. 2014; Cammaerts and Johansson, 2014). Studies are carried out under laboratory conditions on model organisms (Cucurachi et al., 2013). Insects are affected negatively by electromagnetic radiation (Balmori 2015). Studies investigated the electromagnetic radiation emitted by mobile telecommunication antennas affects the abundance and diversity of wild pollinators (Tscheulin, et al. 2010, Hill, and Bartomeus, 2016, Shepherd, 2018, Egdogan and Cengiz, 2019, Sanchez-Bayo and Wyckhuys, 2019).

Pollinators and pollination under threat: Many anthropogenic activities may result in global environmental change, which may act as a threat to global insect biodiversity and to nature (Hallmann et al., 2017; IPBES, 2016; Potts et al., 2016; Sánchez-Bayo and Wyckhuys, 2019). Based on their importance, status and trends, insect pollinators are facing threats and particularly high on the science and policy agenda worldwide (IPBES, 2016). Major pressures impacting pollinators and pollination services include use and misuse of pesticides, intensive agricultural management, land-use change, climate change, pests and pathogens, alien invasive species (Vanbergen, 2013; Brown et al., 2016; IPBES, 2016).

Environmental pollution is another risk to pollinators and pollination, although its impact is much less studied (IPBES, 2016). The global spread of anthropogenic electromagnetic radiation such as radio waves, microwaves, infrared, visible light, ultraviolet, $\mathrm{X}$-rays, and gamma radiation is a form of pollution, which is a potential risk to wildlife (Balmori, 2015; Bandara and Carpenter, 2018; Grubisic et al., 2018; Russell, 2018). WHO recognized the risk of human health, from nonionizing anthropogenic Electromagnetic Radiations (up to $300 \mathrm{GHz}$ ). At present, neither the WHO nor the OECD (OECD, 2012), have reported the current or future indirect risks from anthropogenic EMR to the natural environment. The artificial light at night (ALAN) and anthropogenic radiofrequency electromagnetic radiation (AREMR) utilized in mobile and smart wireless technologies are increasing globally for increasing urbanization and the worldwide launch of nextgeneration wireless technologies and the Internet of Things (Macgregor et al., 2015; Bandara and Carpenter, 2018; Bin Zikria et al., 2018; Russell, 2018).

Effects of artificial light at night (ALAN): The artificial light at night has been reported as a potential risk to nocturnal pollinators and pollination (Macgregor et al., 2015) and mentioned in the Intergovernmental Science-Policy Platform on Biodiversity and Ecosystem 
Services (IPBES) assessment of pollinators and pollination as "a driver clearly affecting nocturnal species and growing in importance due to urbanization". The IPBES also noted that compared to other drivers effects of artificial light at night is still scarcely studied and called for further studies to assess the degree of light pollution effects on nocturnal pollinators (IPBES, 2016). The artificial light altered the architecture of communities of nocturnal pollinator and reduced the visitation rates to plants by $62 \%$ leading to a $13 \%$ drop in the fruit set of a focal plant species (Cirsium oleraceum, Asteraceae) (Knop et al., 2017). Some studies have reported the effects of artificial street lighting on the reduction of local species richness, abundance, rates of pollen transport and feeding in moths (Macgregor, et al., 2017; van Langevelde, et al., 2017; Grubisic, et al., 2018).

Study on combined diurnal and nocturnal plantpollinator interaction revealed that light pollution transmitted to the diurnal animals through a trophic association between nocturnal and diurnal species (Knop et al., 2017). Other studies reported the influence of Artificial light at night (ALAN) in impairment of behaviour of diurnal pollinators (Vanbergen, 2013; Potts et al., 2016).

Effects of anthropogenic radiofrequency electromagnetic radiation (AREMR): Apart from ALAN, the IPBES report (IPBES, 2016; Potts et al., 2016) has not reported other sources and wavelengths of anthropogenic EMR. It was due to insufficient data for an evidence assessment, with only a few studies considered utilization of magnetic fields by bees for foraging behaviour (Clarke et al., 2013; Gould et al., 1978; Hsu and $\mathrm{Li}, 1994)$ and few workers recognized the potential effects of AREMR (Greenberg et al., 1981; Favre, 2011). Another study related to biodiversity conservation, natural capital and ecosystem services, reported the potential, but unstudied threats of wildlife in form of non-ionizing radiation from wireless transmission setups and $5 \mathrm{G}$ mobile phones (Sutherland et al., 2018).

In addition to ALAN, AREMR is reported as a growing risk to pollinators and pollination (Balmori, 2015). Other studies revealed that honey bees (Apis mellifera) can detect magnetic fields physiologically (Gould et al., 1978; Kirschvink and Kirschvink, 1991; Hsu and Li, 1994; Liang et al., 2016; Lambinet et al., 2017) and can use this capability for navigation, orientation and foraging behaviours. Additionally, honey bees use electric fields of the same magnitude as commonly encountered AREMR for intraspecific and interspecific communication for foraging on floral resources (Clarke, et al., 2013; Greggers, et al., 2013). Therefore, it has been concluded that AREMR can disorder the physiological functions and affecting bee health and survival of honeybee.

Experimental studies on EMR exposure to pollinators: Several scientific laboratory experiments have considered that insects can detect and may orientate using electromagnetic fields and affect behaviour, cell development and physiological function (Wan et al., 2014; Bae et al., 2016; Sutton et al., 2016; Tomanova and Vacha, 2016). Based on a few experimental studies, little evidence of exposure to EMR has been reported, which may affect the development, reproduction in animals (Wan et al., 2014; Bae et al., 2016; Wyszkowska et al., 2016; Zhang et al., 2016). Most of studies are related to the effects of EMR on cockroach (Vacha, 2009), birds (Engels et al., 2014) and mammals (Malkemper, et al., 2015). Acute exposure (20 to $\mathrm{N} 100 \mu \mathrm{T}$ EMF) had a clear negative impact on learning and memory in the honeybee workers (Shepherd, et al., 2018).

A study has been carried out on the effects of EMF ( 5 $-15 \mu \mathrm{T}$ ) on behaviour and cognition in bee (Burda et al., 2009). Other effects of $\operatorname{EMF}(100 \mu \mathrm{T})$ on the foraging and flight rate on a sugar source have been reported in worker bee, which can alter the foraging in the ground vegetation (Shepherd et al., 2018).

Experiment on honey bees reported that very close proximity to AREMR $(900 \mathrm{MHz})$ could affect acoustic and swarming behaviour (Favre, 2011). Another experimental study showed that exposure of AREMR increased mortality during pupation and reduced hatching rate of the new queens (Odemer and Odemer, 2019). In an entomological study of wild pollinator communities around 10 mobile phone antennas with high frequencies $(800-2600 \mathrm{MHz})$, major effects have been reported on insect abundance (Lazaro et al., 2016). This study revealed a correlation between insect abundance and anthropogenic electric field, measured at distance intervals $(50,100,200$ and 400 $\mathrm{m}$ ) from the antenna, but varied with geographical locations. Greater exposure to EMR was related positively to underground nesting wild bees and bee flies, negatively to hoverflies; wasps, or uncorrelated to butterflies in terms of abundance (Lazaro et al., 2016). Another field study on phylogenetically unrelated invertebrate taxa such as Collembola, Heteroptera, Hymenopteran parasitoid and Drosophila melanogaster, reported no effects on reproductive capacity in animals exposed to EMR from a mobile antenna (Vijver et al., 2014).

Recommendations for future research: Further research is required to evaluate the potential threat to pollinators and other invertebrates from exposure to anthropogenic EMR. More research studies are required to assess the unstudied effects of emerging AREMR technologies on pollinators and another biodiversity (Bandara and Carpenter, 2018; Bin Zikria et al., 2018; Russell, 2018). Good quality scientific investigations must improve to obtain an accurate level of the level of risk (Makinistian, et al., 2018). As reported by other researchers (Gonzalez-Varo, et al., 2013; Vanbergen, 2013; Godfray, et al., 2014), assessments of chronic exposure and synergistic effects arising from exposure to sources of ALAN/AREMR and other 
stressors such as pesticides, pathogens, nutritional deficits need testing to evaluate the overall level of risk from anthropogenic EMR. To understand exposure and effects requires consideration of traits of pollinator species, such as nesting habits, foraging or dispersal behaviour and sociality, which govern the level of impact of different sources of anthropogenic EMR (Vanbergen, 2013; Potts, et al., 2016). Measurement of pollinator responses to EMR exposure at different biological levels such as species, population, community and resulting change crop yield over the longerterm exposure would be especially valuable. Interdisciplinary collaborators (engineers, physicists, ecotoxicologists and biologists) must come together, to test hypotheses about biological impacts of exposure of anthropogenic EMR (Makinistian et al., 2018) on pollinators and other insects.

\section{Conclusion}

Some recent evidence revealed the effects of ALAN on pollinator communities, although there is a need for further high-quality studies to conclude its role as a major threat to pollinators. Due to the lack of highquality scientific research, knowledge about the impact of AREMR on invertebrates and other pollinators is inadequate and is hindered. Most of experimental as well as field studies are failed due to unavailability of good scientific methods, improper reporting of technical and scientific details. The anthropogenic EMR (ALAN or AREMR) is considered as a significant threat to insect pollinators. The abundance and composition of wild pollinators in natural habitats are affected by electromagnetic radiation from telecommunication antennas. Studies reported that the effects of EMR on the abundance of different pollinator groups might be due to different susceptibilities of larval stages to radiation. Anthropogenic EMR emissions are proliferating, but more research study is required to study the adverse impacts on pollinators and pollination.

\section{Conflict of interests}

There is no conflict of interest regarding the publication of this article.

\section{REFERENCES}

1. Adam, J. Vanbergen, Simon G., Potts, AlainVian, E. Pascal Malkemper, JulietteYoung, Thomas Tscheulin (2019). Risk to pollinators from anthropogenic electro-magnetic radiation (EMR): Evidence and knowledge gaps. Science of The Total Environment, 695, 133833. https:// doi.org/10.1016/j.scitote nv.2019.13 3833 .

2. Aguero, J.I., Pérez-Mendez, N., Torretta, J.P. and Garibaldi, L.A. (2020). Impact of invasive bees on plant-pollinator interactions and reproductive success of plant species in mixed Nothofagus Antarctica forests. Neotrop Entomol., Aug; 49 (4):557-567. https://doi.org/10.1007/s13744-02000787-6.

3. Aguilar, R., Ashworth, L., Galetto, L. and Aizen, M. (2006). Plant reproductive susceptibility to habitat fragmentation: review and synthesis through a meta-analysis. Ecol. Lett., 9:968-980. DOI: 10.1111/j.1461-0248.2006.00927.x.

4. Ashman, T.L., Knight, T.M., Steets, J.A., Amarasekare, P., Burd, M., Campbell, D.R., Dudash, M.R., Johnston, M.O., Mazer, S.J., Mitchell, R.J., Morgan, M.T. and Wilson, W.G. (2004). Pollen limitation of plant reproduction: ecological and evolutionary causes and consequences. Ecology, 85:2408-2421. http://dx.doi.org/10.1890/03-8024.

5. Atli, E, U" nlu" H. (2006). The effects of microwave frequency electromagnetic fields on the development of Drosophila melanogaster. Int. J. Radiat. Biol., 82:435-441.

6. Atli, E, U" nlu" H. (2007). The effects of microwave frequency electromagnetic fields on the fecundity of Drosophila melanogaster. Turkish J. Biol., 31:1-5.

7. Bae, J.E., Bang, S., Min, S., Lee, S.H., Kwon, S.H., Lee, Y. (2016). Positive geotactic behaviors induced by geomagnetic field in Drosophila. Mol. Brain., 9(1)55. https:// doi.org/10.1186/s13041-016-0235-1.

8. Balmori, A. (2015). Anthropogenic radiofrequency electromagnetic fields as an emerging threat to wildlife orientation. Sci. Total Environ., 518-519:58-60. DOI: 10.1016/ j.scitotenv.2015.02.077.

9. Bandara, P. and Carpenter, D.O. (2018). Planetary electromagnetic pollution: it is time to assess its impact.2 (12):E512-E514. DOI:https://doi.org/10.1016/S2542-5196 (18)30221-3.

10.Bhatia, R., Gupta, D., Chandel, J. S. and Sharma, N. K. (1995). Relative abundance of insect visitors on flowers of major subtropical fruits in Himachal Pradesh and their effect on fruit set. Indian Jour. Agric. Sci., 65: 907-912.

11.Biesmeijer, J.C., Roberts, S.P.M., Reemer, M., Ohlemuller, R., Edwards, M., Peeters, T., Schaffers, A.P., Potts, S.G., Kleukers, R., Thomas, C.D., Settele, J. and Kunin, W.E. (2006). Parallel declines in pollinators and insectpollinated plants in Britain and the Netherlands. Science, 313:351-354. DOI: 10.1126/science.1127863.

12.Bin Zikria, Y., Kim, S.W., Afzal, M.K., Wang, H.X. and Rehmani, M.H. (2018). 5G Mobile services and scenarios: challenges and solutions. Sustainability, 10. https:// doi.org/10.3390/su10103626.

13.Brown, M.J.F., Dicks, L.V., Paxton, R.J., Baldock, K.C.R., Barron, A.B., Chauzat, M, Freitas, B.M., Goulson, D., Jepsen, S., Kremen, C., Li, J., Neumann, P., Pattemore, D.E., Potts, S.G., Schweiger, O., Seymour, C.L., Stout, J.C. (2016). A horizon scan of future threats and opportunities for pollinators and pollination. PeerJ, 4:e2249 https://doi.org/10.7717/peerj.2249.

14.Burda, H., Begall, S., Cerveny, J., Neef, J. and Nemec, P. (2009). Extremely low-frequency electromagnetic fields disrupt magnetic alignment of ruminants. Proc. Natl. Acad. Sci. U. S. A. 106, 5708-5713. doi: 10.1073/pnas.0811 194106.

15.Burkle, L.A., Marlin, J.C. and Knight, T.M. (2013). Plantpollinator interactions over 120 years: loss of species, cooccurrence and function. Science, 339:1611-1615. doi: 10.1126/science.1232728.

16.Cammaerts, M.C., De Doncker, P., Patris, X., Bellens, F., Rachidi, Z. and Cammaerts, D. (2012). GSM $900 \mathrm{MHz}$ radiation inhibits ants' association between food sites and encountered cues. Electromagn. Biol. Med., 31:151-165. doi: 10.3109/15368378.2011.624661.

17.Cammaerts, M. C. and Johansson, O. (2014). Ants can be used as bioindicators to reveal biological effects of electromagnetic waves from some wireless apparatus. Electromagn. Biol. Med. 33:282-288. doi: 10.3109/15368 
378.2013.817336.

18.Cammaerts, M.C., Vandenbosch, G.A.E. and Volski, V. (2014). Effect of short-term GSM radiation at representative levels in society on a biological model: the ant Myrmica sabuleti. J. Insect. Behav. 27:514-526. DOI: 10.1007/ s10905-014-9446-4.

19.Chavdoula, E.D., Panagopoulus, D.J., Margaritis, L.H. (2010). Comparison of biological effects between continuous and intermittent exposure to GSM-900-MHz mobile phone radiation: detection of apoptotic cell-death features. Mutat. Res. 700:51-61.

20.Chiawo, D. O., Ogol, C. K. P. O., Kioko, E. N., Otiende, V. A. and Gikungu, M. W. (2017). Bee diversity and floral resources along a disturbance gradient in Kaya Muhaka forest and surrounding farmlands of coastal Kenya. Jour. Poll. Ecol., 20, 51-59. http://dx.doi.org/10.26786/19207603\%282017\%29five.

21.Clarke, D., Whitney, H., Sutton, G. and Robert, D. (2013). Detection and learning of floral electric fields by bumblebees. Science, 340, 66-69. doi: 10.1126/science.123 0883.

22.Cucurachi, S., Tamis, W.L.M., Vijver, M.G., Peijnenburg, W.J.G.M., Bolte, J.F.B. and de Snoo, G.R. (2013). A review of the ecological effects of radiofrequency electromagnetic fields (RF-EMF). Environ. Int. 51:116-140. DOI: 10.1016/j.envint.2012.10.009.

23.Dag, A. and Gazet, S. (2000). Mango pollinators in Israel. Jour. Applied Horticulture, Lucknow. 2 (1): 39-43.

24.De Santis, A.A.A. and Chacoff, N.P.C. (2020). Urbanization affects composition but not richness of flower visitors in the Yungas of Argentina. Neotrop Entomol. https:// doi.org/10.1007/s13744-020-00772-z.

25.Dimobe, K., Goetze, D., Ouédraogo, A., Forkuor, G., Wala, K., Porembski, S. and Thiombiano, A. (2017). Spatio-temporal dynamics in land use and habitat fragmentation within a protected area dedicated to tourism in a Sudanian savanna of West Africa. Jour. Landsc. Ecol., 10, 5 -25. DOI: https://doi.org/10.1515/jlecol-2017-0011.

26.Driessen, S., Bodewein, L., Dechent, D., Graefrath, D., Schmiedchen, K., Stunder, D. (2020). Biological and health-related effects of weak static magnetic fields $(\leq 1$ $\mathrm{mT}$ ) in humans and vertebrates: A systematic review. PLoS ONE 15(6): e0230038. https://doi.org/10.1371/ journal.pone. 0230038 .

27.Egdogan, Y. and Cengiz, M.M. (2019). Effect of Electromagnetic Field (EMF) and Electric Field (EF) on Some Behavior of Honey Bees (Apis mellifera L.) $3^{\text {rd }}$ International conference on Advance Ennering Technologies 19-21 September 2019 Bayburt/ TURKEY. https://doi.org/10.11 $01 / 608182$.

28.Engels, S., Schneider, N.L., Lefeldt, N., Hein, C.M., Zapka, M. and Michalik, A. (2014). Anthropogenic electromagnetic noise disrupts magnetic compass orientation in a migratory bird. Nature, 509, 353. doi: 10.1038/ nature 13290.

29.Evenhuis, N. L., Pape, T. Pontand, A. C. and Thompson, F. C. (2008). Biosystematic database of World Diptera, Version 10.http://www.diptera.org/biosys.htm, accessed on 20 January 2008.

30.Favre, D. (2011). Mobile phone-induced honeybee worker piping. Apidologie, 42, 270-279. DOI: 10.1007/s13592011-0016-x.

31.Godfray, H.C.J., Blacquiere, T., Field, L.M., Hails, R.S., Petrokofsky, G. and Potts, S.G. (2014). A restatement of the natural science evidence base concerning neonico- tinoid insecticides and insect pollinators. Proc. R. Soc. B. Biol. Sci. 281. doi: 10.1098/rspb.2014.0558.

32.Godfray, H.C.J., Blacquière, T., Field, L.M., Hails, R.S., Potts, S.G. and Raine, N.E. (2015). A restatement of recent advances in the natural science evidence base concerning neonicotinoid insecticides and insect pollinators. Proc. R. Soc. Lond. B Biol. Sci. 282. https://doi.org/10.109 8/rspb.2015.1821.

33.Gonzalez-Varo, J.P., Biesmeijer, J.C., Bommarco, R., Potts, S.G., Schweiger, O. and Smith, H.G.(2013). Combined effects of global change pressures on animalmediated pollination. Trends Ecol. Evol. 28, 524. doi: 10.1016/j.tree.2013.05.008.

34.Gould, J.L., Kirschvink, J.L. and Deffeyes, K.S. (1978). Bees have magnetic remanence. Science 201, 10261028. DOI: $10.1126 /$ science.201.4360.1026.

35.Goulson, D., Lye, G.C. and Darvill, B. (2008). Decline and conservation of bumble bees. Annu. Rev. Entomol. 53:191-208. https://doi.org/10.1146/annurev.ento.53.1 03106.093454

36.Greenberg, B., Bindokas, V.P., Frazier, M.J. and Gauger, J.R. (1981). Response of honey bees, Apis mellifera L., to high-voltage transmission lines. Environ. Entomol. 10, 600 -610. doi: 10.1093/ee/10.5.600.

37.Greggers, U., Koch, G., Schmidt, V., Durr, A., FloriouServou, A. and Piepenbrock, D. (2013). Reception and learning of electric fields in bees. Proc. R. Soc. B Biol. Sci. 280. http://dx.doi.org/10.1098/rspb.2013.0528.

38.Grubisic, M., van Grunsven, R.H.A., Kyba, C.C.M., Manfrin, A. and Holker, F. (2018). Insect declines and agroecosystems: does light pollution matter? Ann. Appl. Biol. 173, 180-189. https://doi.org/10.1111/aab.12440.

39.Halder, S., Ghosh, S., Khan, R., Khan, A., Perween, T. and Md. A Hasan (2019). Role of pollination in fruit crops: A review. The Pharma Innov. Jour. 8(5): 695-702.

40.Hallmann, C.A., Sorg, M., Jongejans, E., Siepel, H., Hofland, N. and Schwan, H. (2017). More than 75 percent decline over 27 years in total flying insect biomass in protected areas. PLoS One 12, e0185809. ttps://doi.o rg/10.1371/journal.pone.0185809

41. Harst, W., Kuhn, J. and Stever, H. (2006). Can electromagnetic exposure cause a change in behaviour? Studying possible non-thermal influences on honeybees-an approach within the framework of educational informatics. Acta Syst IIAS Int J 6(1):1-6.

42.Hegland, S.J., Nielsen, A., Lazaro, A., Bjerknes, A.L., Totland, $\varnothing$. (2009) How does climate warming affect plant -pollinator interactions? Ecol Lett 12:184-195. doi: 10.1111/j.1461-0248.2008.01269.x.

43. Hill, B. and Bartomeus, I.(2016). The potential of electricity transmission corridors in forested areas as bumblebee habitat. Open Science 3, 160525. https://doi.org/10.1098/ rsos. 160525.

44.Hsu, C. Y. and Li, C. W. (1994). Magnetoreception in honeybees. Science, 265, 95-97. doi: 10.1126/ science.265.5168.95.

45.Hunicken, P.L., Morales, C.L., Garcia, N. and Garibaldi, L.A. (2020). Insect pollination, more than plant nutrition, determines yield quantity and quality in apple and pear. Neotropical Entomology 49(10). DOI: 10.1007/s13744020-00763-0

46.IPBES (2016). In: Potts, S.G., Imperatriz-Fonseca, V.L., Ngo, H.T. (Eds.), The Assessment Report of the Intergovernmental Science-Policy Platform on Biodiversity and Ecosystem Services on Pollinators, Pollination and Food 
Production. Secretariat of the Intergovernmental Science -Policy Platform on Biodiversity and Ecosystem Services, Bonn, Germany.

47.Kearns, C., Inouye, D. and Waser, N. (1998). Endangered mutualisms: the conservation of plant-pollinator interactions. Annu. Rev. Ecol. Syst., 29:83-112. https:// doi.org/10.1146/annurev.ecolsys.29.1.83

48.Kirschvink, J.L. and Kirschvink, A.K. (1991). Is geomagnetic sensitivity real - replication of the Walker-Bitterman magnetic conditioning experiment in honey bees? Am. Zool., 31, 169-185.

49.Kirschvink, J.L., Walker, M.M. and Diebel, C. (2001). Magnetite-based magnetoreception. Curr. Opin. Neurobiol., 11:462-467.

50.Klein, A.M., Vaissiere, B.E., Cane, J.H., Dewenter, I.S., Cunningham, S.A., Kremen, C. and Tscharntke, T. (2007). Importance of pollinators in changing landscapes for world crops. Proc. R. Soc. Lond. B. Biol. Sci., 274:303 -313. https://doi.org/10.1098/rspb.2006.3721.

51.Knop, E., Zoller, L., Ryser, R., Erpe, C.G., Horler, M. and Fontaine, C. (2017). Artificial light at night as a new threat to pollination. Nature, 548, 206.

52.Kremen, C., Williams, N.M., Aizen, M.A., GemmillHerren, B., LeBuhn, G., Minckley, R., Packer, L., Potts, S.G., Roulston, T., Steffan-Dewenter, I., Vazquez, D.P., Winfree, R., Adams, L., Crone, E.E., Greenleaf, S.S., Keitt, T.H., Klein, A.M., Regetz, J. and Ricketts, T.H. (2007). Pollination and other ecosystem services produced by mobile organisms: a conceptual framework for the effects of land-use change. Ecol. Lett. 10:299-314.

53.Lambinet, V., Hayden, M.E., Reigl, K., Gomis, S. and Gries, G. (2017). Linking magnetite in the abdomen of honey bees to a magnetoreceptive function. Proc. $R$. Soc. B Biol. Sci., 284, 20162873. https://doi.org/10.1098/ rspb.2016.2873.

54.Larson, B. M. H., Kevan, P. G. and Inouye, D. W. (2001). Flies and flowers: The taxonomic diversity of anthophiles and pollinators. Canadian Entomologist, 133(4): 439-465.

55.Lázaro, A., Chroni, A., Tscheulin, T., Devalez, J., Matsoukas, C. and Petanidou, T. (2016). Electromagnetic radiation of mobile telecommunication antennas affects the abundance and composition of wild pollinators. J. Insect Conserv., 20, 315-324.

56.Liang, C.H., Chuang, C.L., Jiang, J.A., Yang, E.C. (2016). Magnetic sensing through the abdomen of the honey bee. Sci. Rep., 6: 23657. doi: 10.1038/srep23657.

57.Macgregor, C.J., Evans, D.M., Fox, R. and Pocock, M.J.O. (2017). The dark side of street lighting: impacts on moths and evidence for the disruption of nocturnal pollen transport. Glob. Chang. Biol., 23: 697-707. https:// doi.org/10.1111/gcb.13371.

58.Macgregor, C.J., Pocock, M.J.O., Fox, R. and Evans, D.M. (2015). Pollination by nocturnal Lepidoptera, and the effects of light pollution: a review. Ecological Entomology, 40:187-198. DOI: 10.1111/een.12174.

59.Makinistian, L., Muehsam, D.J., Bersani, F. and Belyaev, I. (2018). Some recommendations for experimental work in magnetobiology, revisited. Bioelectromagnetics, 39, 556-564. doi: 10.1002/bem.22144.

60.Malkemper, E.P., Eder, S.H.K., Begall, S., Phillips, J.B. Winklhofer, M. and Hart, V. (2015). Magnetoreception in the wood mouse (Apodemus sylvaticus): influence of weak frequency-modulated radiofrequency fields. Sci. Rep., 5: 9917. doi:10.1038/srep09917.
61.Malkemper, E. P., Tscheulin, T., Vanbergen, A. J., Vian, A., Balian, E. and Goudeseune, L. (2018). The impacts of artificial Electromagnetic Radiation on wildlife (flora and fauna). Current knowledge overview: a background document to the web conference. A report of the EKLIPSE project.

62.Marques, R.D., Lima, M.A.P., Marques, R.D. and Bernardes, R.C. (2020). A spinosadbased formulation reduces the survival and alters the behavior of the stingless bee Plebeia lucii. Neotrop Entomol., 49(4).https:// doi.org/10.1007/ s13744-020-00766-x.

63.Odemer, R. and Odemer, F. (2019). Effects of radiofrequency electromagnetic radiation (RFEMF) on honey bee queen development and mating success. Sci. Total Environ., 661, 553-562. DOI: 10.1016/j.scitotenv.2019.01.154.

64.OECD (2012). Environmental Outlook to 2050: The Consequences of Inaction. p. 350.

65.Panagopoulos, D.J., Karabarbounis, A, Margaritis, L.H. (2004). Effect of GSM 900-MHz mobile phone radiation on the reproductive capacity of Drosophila melanogaster. Electromagn. Biol. Med., 23:29-43.

66.Panagopoulos, D.J., Chavdoula, E.D., Nezis, I.P. and Margaritis, L.H. (2007). Cell death induced by GSM 900$\mathrm{MHz}$ and DCS $1800-\mathrm{MHz}$ mobile telephony radiation. Mutat. Res., 626:69-78.

67.Panagopoulos, D.J., Chavdoula, E.D. and Margaritis, L.H. (2010). Bioeffects of mobile telephony radiation in relation to its intensity or distance from the antenna. Int. J. Radiat. Biol., 86:345-357.

68.Pauw, A. (2007). Collapse of a pollination web in small conservation areas. Ecology, 88:1759 1769. https:// www.jstor.org/stable/27651293.

69.Potts, S.G., Petanidou, T., Roberts, S., O.,Toole, C., Hulbert, A., Willmer, P. (2006). Plant-pollinator biodiversity and pollination services in a complex Mediterranean landscape. Biol. Conserv., 129:519-529. doi:10.1016/ j.biocon.2005.11.019.

70.Potts, S.G., Biesmeijer, J.C., Kremen, C., Neumann, P., Schweiger, O. and Kunin, W.E. (2010). Global pollinator declines: trends, impacts and drivers. Trends Ecol. Evol., 25:345-353. doi: 10.1016/j.tree.2010.01.007.

71.Potts, S.G., Imperatriz-Fonseca, V., Ngo, H.T., Aizen, M.A., Biesmeijer, J.C. and Breeze, T.D. (2016). Safeguarding pollinators and their values to human well-being. Nature, 540: 220 229. doi: 10.1038/nature20588.

72.Russell, C.L. (2018). 5 G wireless telecommunications expansion: public health and environmental implications. Environ. Res., 165, 484-495. doi: 10.1016/ j.envres.2018.01.016.

73.Sahib, S.S. (2011). Impact of mobile phones on the density of honeybees. J. Public Adm Policy Res. 3:131-137.

74.Sanchez-Bayo, F. and Wyckhuys, K.A.G. (2019). Worldwide decline of the entomofauna: a review of its drivers. Biol. Conserv., 232, 8-27. https://doi.org/10.1016/ j.biocon.2019.01.020.

75.Sawe, T., Nielsen, A. and Eldegard, K. (2020). Crop pollination in small-scale agriculture in Tanzania: Household Dependence, Awareness and Conservation, Sustainability 2020, 12, 2228; doi:10.3390/su12062228.

76.Sharma, V.P. and Kumar, N.R. (2010). Changes in honeybee behaviour and biology under the influence of cellphone radiations. Curr. Sci., 98:1376-1378.

77.Shepherd, S., Lima, M.A.P., Oliveira, E.E., Sharkh, S.M., Jackson, C.W. and Newland, P.L.(2018). Extremely low 
frequency electromagnetic fields impair the cognitive and motor abilities of honey bees. Sci. Rep., 8. 10.1038/ s41598-018-26185-y.

78.Singh, G. (1988). Insect pollinators of mango and their role in fruit setting. Acta Hort., 231: 629-632.

79.Singh, G. (1997). Pollination, pollinators and fruit setting in mango. Acta Hort., 455: 116123.

80.Stein, K., Stenchly, K., Coulibaly, D., Pauly, A., Dimobe, K., Steffan-Dewenter, I., Konate, S., Goetze, D., Porembski, S. and Linsenmair, K. E. (2018). Impact of human disturbance on bee pollinator communities in savanna and agricultural sites in Burkina Faso, West Africa. Ecology and Evolution. 2018;8:6827-6838.DOI: 10.1002/ ece3.4197.

81.Sutherland, W.J., Butchart, S.H.M., Connor, B., Culshaw, C., Dicks, L.V. and Dinsdale, J. (2018). A 2018 horizon scan of emerging issues for global conservation and biological diversity. Trends Ecol. Evol., 33: 47-58. doi: 10.1016/j.tree.2017.11.006.

82.Sutton, G.P., Clarke, D., Morley, E.L. and Robert, D. (2016). Mechanosensory hairs in bumblebees (Bombus terrestris) detect weak electric fields. Proc. Natl. Acad. Sci. U. S. A. 113: 7261-7265. doi: 10.1073/pnas.1601 62 4113.

83.Tangtorwongsakul, P., Warrit, N. and Gale, G. A. (2018). Effects of landscape cover and local habitat characteristics on visiting bees in tropical orchards. Agricul. and For.t Entomol., 20, 28-40. https://doi.org/10.1111/afe.12226.

84.Tomanova, K. and Vacha, M. (2016). The magnetic orientation of the Antarctic amphipod Gondogeneia antarctica is cancelled by very weak radiofrequency fields. J. Exp. Biol. 219, 1717-1724. doi: 10.1242/jeb.132878.

85.Tscheulin, T., Spyropoulos, A. and Petanidou, T. (2010). Impacts of mobile phone masts on the abundance of pollinators. In: 5th Conference of the Hellenic Ecological Society, Patras, p 201.

86.Vacha, M., Puzova, T. and Kvicalova, M. (2009). Radiofrequency magnetic fields disrupt magnetoreception in American cockroach. J. Exp Biol 212:3473-3477. doi: 10.1242/jeb.028670.

87.Valkova, T. and Vacha, M. (2012). How do honeybees use their magnetic compas? Can they see the North? Bull. Entomol. Res., 102:461-467. doi: 10.1017/ S0007485311000824.

88.van Langevelde, F., van Grunsven, R.H.A., Veenendaal, E.M. and Fijen, T.P.M. (2017). Artificial night lighting in- hibits feeding in moths. Biol. Lett., 13. doi: 10.1098/ rsbl.2016.0874.

89.Vanbergen, A.J. (2013). Threats to an ecosystem service: pressures on pollinators. Front. Ecol. Environ., 11, 251259. https://doi.org/10.1890/120126.

90.Vijver, M.G., Bolte, J.F.B., Evans, T.R., Tamis, W.L.M., Peijnenburg, W.J.G.M., Musters, C.J.M. and de Snoo, G.R. (2013). Investigating short-term exposure to electromagnetic fields on reproductive capacity of invertebrates in the field situation. Electromagn. Biol. Med., 33(1):2128.

91.Vijver, M.G., Bolte, J.F., Evans, T.R., Tamis,W.L., Peijnenburg,W.J. and Musters, C.J. (2014). Investigating short-term exposure to electromagnetic fields on reproductive capacity of invertebrates in the field situation. Electromagn, Biol. Med., 33, 21-28. https:// doi.org/10.3109/15368378.2013.783846.

92.Wajnberg, E., Acosta-Avalos, D., Alves, O.C., de Oliviera, J.F., Srygley, R.B. and Esquivel, D.M. (2010). Magnetoreception in eusocial insects: an update. J. R. Soc. Interface 7:S207-S225. doi: 10.1098/rsif.2009.0526.focus.

93.Wan, G.J., Jiang, S.L., Zhao, Z.C., Xu, J.J., Tao, X.R. and Sword, G.A. (2014). Bio-effects of near-zero magnetic fields on the growth, development and reproduction of small brown planthopper, Laodelphax striatellus and brown planthopper, Nilaparvata lugens. J. Insect Physiol., 68, 7-15. DOI: 10.1016/j.jinsphys.2014.06.016.

94.Warnke, U. (2009). Bees, birds and mankind: destroying nature by 'Electrosmog' effects of wireless communication technologies. A Brochure series by the competence initiative for the protection of humanity, environment and democracy, Kempten, 1st edn, November 2007, ISBN: 978-3 -00-023124-7, English edn, March 2009, pp 14-33.

95.Weisbrot, D., Lin, H., Ye, L., Blank, M. and Goodman, R. (2003). Effects of mobile phone radiation on reproduction and development in Drosophila melanogaster. J. Cell Biochem., 89:48-55.

96.Wyszkowska, J., Shepherd, S., Sharkh, S., Jackson, C.W. and Newland, P.L. (2016). Exposure to extremely low frequency electromagnetic fields alters the behaviour, physiology and stress protein levels of desert locusts. Sci. Rep. 6, 36413.

97.Zhang, Z.Y., Zhang, J., Yang, C.J., Lian, H.Y., Yu, H. and Huang, X.M. (2016). Coupling mechanism of electromagnetic field and thermal stress on Drosophila melanogaster. PLoS One, 11: e0162675. 